\title{
Miller I-Il ínyrecesszióval kombinált fognyaki léziók restauratív és sebészi ellátása - randomizált, kontrollált klinikai vizsgálat 6 hónapos eredményei
}

\author{
DR. PAPP ZSUZSANNA, DR. GERA ISTVÁN, DR. ERDŐS ZSUZSANNA, DR. HORVÁTH ATTILA
}

\begin{abstract}
Cél: Jelen klinikai vizsgálat célja, hogy nem kárieszes cervikális lézióval (NCCL) társuló Miller I-II típusú tükörszimmetrikus ínyrecessziók mútéti korrekciója során megvizsgáljuk, hogy egy nanotechnológiás polimerlakkal fedett üvegionomer tömőanyag (GIC) milyen sikerrel használható NCCL komplex sebészi-restauratív ellátásában. Továbbá vizsgáltuk, hogy a kötőszöveti graft (SCTG), illetve zománc mátrix derivátum (EMD) használata javít-e az eredményeken.

Anyag és módszer: 20 parodontálisan egészséges páciens, 40 tükörszimmetrikusan elhelyezkedő NCCL-val rendelkező Miller I-Il típusú ínyrecesszióját vizsgáltuk. A főbb vizsgálati paraméterek a recesszió mélysége (AGR) és szélessége (IRSZ), klinikai tapadási nívó (CAL), tasakmélység (PD), ínyvérzési index (BOP) és szubjektív fognyaki érzékenység (DE) voltak. A pácienseket elektronikus randomizációval mútét előtt két csoportra osztottuk annak eldöntésére, hogy a mindkét oldalon alkalmazott módosított koronálisan elcsúsztatott lebenytechnikát (MCAF) SCTG-tal (MCAT-SCTG csoport), vagy EMD-mal (MCAT-EMD csoport) egészítsük ki. További elektronikus randomizáció alapján a töméssel ellátandó oldalakat választottuk ki. A teszt oldalon (T) Equia ${ }^{\circledR}$ (GC Europe, Leuven, Belgium) tömőanyag került behelyezésre, míg a kontroll oldalon az abradált dentin felszínén csupán gyökérsimítást végeztünk.

Eredmények: Mútétek után hat hónap elteltével mindkét sebészi technika a T és $\mathrm{K}$ fogaknál is statisztikailag szignifikánsan csökkentette az AGR-t és IRSZ-t és javította a CAL-t $(p \leq 0,05)$. A fognyaki fedés mértéke az MCAF-SCTG csoportban közel megegyezett a T (76,92 $\pm 19,23 \%)$ és a K oldalon $(73,07 \pm 21,93 \%)$. Az MCAF+EMD csoportban viszont a T oldal $(40,0 \pm 32,0 \%)$ elmaradt a $\mathrm{K}$ oldal $(66,66 \pm 35,0 \%)$ értékeitől. A BOP értékek statisztikailag szignifikáns mértékben emelkedtek $T$ oldali fogaknál a $\mathrm{K}$ oldalhoz képest, sebészi terápiától függetlenül. $A \mathrm{PD}$ értékek romlottak a T oldalon a K oldalhoz képest, sőt a PD növekedés statisztikailag szignifikáns mértéket öltött a SCTG csoportban az EMD csoporthoz képest. A DE minden csoportban statisztikailag szignifikánsan csökkent, kivéve az MCAF-EMD K csoportját, ahol a csökkenés nem volt szignifikáns.

Következtetések: Vizsgálati eredményeinket összefoglalva megállapíthatjuk, hogy ínyrecesszió fedésére töméssel vagy tömés nélkül mindkét sebészi módszer alkalmas volt. A fognyaki érzékenység csökkentésére az MCAF-EMD tömés nélkül nem elegendő. A vizsgált nanotöltésű polimerlakkal fedett GIC alkalmazása bármelyik műtéti technika kiegészítéseként jelentősen csökkentette a fognyaki érzékenységet, ugyanakkor szubgingivális kiterjesztése nagyobb szondázási tasakmélységgel és gyulladásra utaló magasabb ínyvérzési értékekkel társul.
\end{abstract}

Kulcsszó: Nem carieses cervikális lézió, ínyrecesszió, dentin/fognyaki érzékenység, módosított koronálisan elcsúsztatott lebeny (MCAF), kötőszöveti graft, zománc mátrix derivátum (EMD), fognyaki fedés

\section{Bevezetés}

A gazdaságilag fejlett országokban a parodontális prevenciónak és a javuló egyéni szájhigiéniás szokásoknak köszönhetően a nagyon jó szájhigiéniájú fiatal és középkorú populációban egyre gyakoribb a bukkális gyulladásmentes ínyrecesszió [2, 19, 43, 57]. Az ínyrecesszió sokszor társul nem kárieszes fognyaki kopással (NCCL) [64], amely egyrészt a páciens számára esztétikai kellemetlenséget okoz és fognyaki érzékenységhez vezet, másrészt megnehezíti az ínyrecesszió mukogingivális sebészi korrekció lehetőségeit is [5].

A gyulladásmentes ínyrecesszió elsődleges oka a fogak nem ideális pozíciója az alveoláris csontban, a vé- kony biotípus, valamint számos lokális traumatizáló faktor. Ezek közül leggyakoribb a fogkefeártalom, abrazív fogkrémek és a nem megfelelóen pozicionált restaurátumok okozta trauma, amely megzavarja a biológiai szélesség fiziológiás egységét [29], valamint utóbbi időben a piercing [30]. Természetesen a plakk okozta ínygyulladás és következményes tapadásveszteség is vezethet ínyrecesszióhoz, de ennek morfológiája és terápiás lehetőségei merőben különböznek a gyulladásmentes ínyrecessziótól [30].

A gyulladásmentes ínyrecesszióval társuló nem kárieszes nyaki léziók multifaktoriális folyamatok következtében alakulnak ki. Általában három fő etiológiai tényezőt különíthetünk el: az abráziót, az okklúziós stressz 


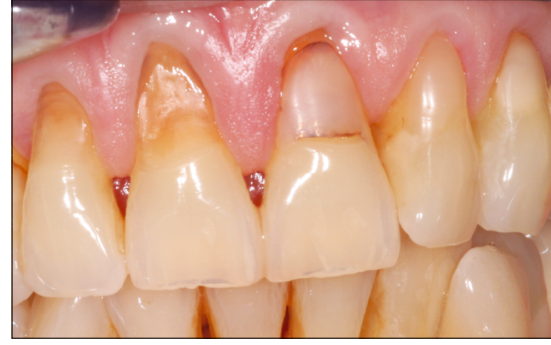

1. kép: Az abrázió, abfrakció és erózió klinikai képe
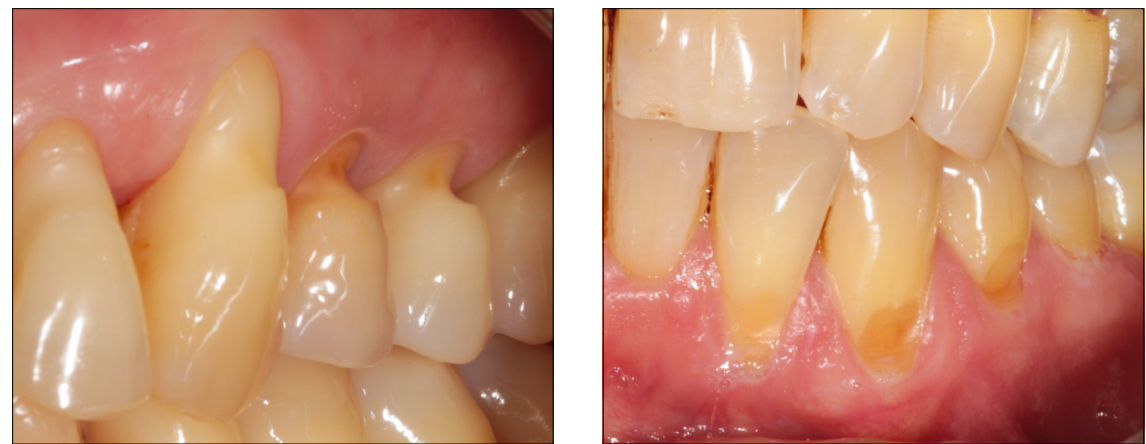

okozta mikrorepedéseket (abfrakció) és a biokorróziót (erózió) [33]. (1. kép. a, b, c)

Az abrázió ismétlődő mechanikai koptató hatás következtében alakul ki [39] és a fog nyaki részén jellegzetes, legömbölyített szélü, ék alakú keményszövethiányt hoz létre. Abfrakció a fog okklúziós túlterhelése következtében a zománc-cement határon kialakuló, ék alakú, éles szélü keményszövethiány. A parafunkciós mozgások a fognyaki területen oldalirányú nyíró erőket produkálnak, a fog mikrométer nagyságrendǔ elhajlását okozva. Ezt az elhajlást a dentin rugalmassága károsodás nélkül követi, azonban a teljesen rigid zománcprizmákban mikro repedések keletkeznek, amik végül a zománc kipattogzásához vezetnek [39, 33]. Klinikai képében az elváltozást az abráziótól a kifejezett, éles széle különíti el [39]. Erózióról beszélünk, ha nem bakteriális eredetű savhatás vagy keláció következtében alakul ki a fogak felszíni demineralizációja [39, 53]. Amennyiben ez a folyamat gyakran ismétlődik és hoszszú ideig tart, különösen, ha abrázióval társul, akkor a fognyaki területen sima felszínú foganyag-veszteség alakulhat ki. Ezen regresszív folyamatokat, a fog keményszövetének fizikai és/vagy kémiai hatásra bekövetkező irreverzibilis anyagveszteségét az angolszász irodalom „non-carious cervical lesion” (NCCL) névvel jelöli [40]. Topográfiai szempontból a léziók érinthetik csak a koronai, vagy csak a gyökérfelszínt, illetve mindkét felszínt egyaránt [8].

A fogak keményszövet ártalmai több esetben az ínyrecesszióval közös etiológiai faktorokat hordoznak, ezért a komplex kezelési tervünk felállításakor fontos megvizsgálnunk, hogy milyen kórfolyamatok húzódnak meg a kombinált lágy- és keményszöveti léziók hátterében. A gyulladásmentes ínyrecesszió és fognyaki kopás közötti kapcsolatot és ennek gyakoriságát jól példázza egy tanulmány, amelyben a megvizsgált 900 ínyrecessziót szenvedett fog közül 50\%-ban nem volt nagyító alatt észlelhető az anatómiai zománc-cement határ $(\mathrm{ZCH})$, ami a fognyaki keményanyag-veszteség biztos jele [82]. Egy másik tanulmány szerint 1000 NCCL-t tanulmányozva 34\%-ban nem volt meghatározható a ZCH vonala [8]. A NCCL ínyszélhez való viszonyát tanulmányozó vizsgálat szerint a cervikális kopás apikális széle az esetek közel 40\%-ában az ínyszélnél, vagy az ínyszél alatt (32\%) helyezkedett el [54, 44].
Annak ellenére, hogy a lágy- és keményszövet patológia ennyire szoros korrelációban van egymással, a restauratív fogászat hosszú ideig figyelmen kívül hagyta a vörös esztétikum korrigálását és csupán a keményszöveti lézióra fókuszált, a szubgingivális szélú fognyaki kopások esetében akár a mukogingivális állapot rovására is [50]. Az elmúlt évtized fogászati ellátásában kiemelt hangsúlyt kap az esztétika, amely már nem csak a keményszövetek esztétikus helyreállítását célozza meg, hanem egyre nagyobb figyelem összpontosul a gingiva egészségére és harmonikus lefutására is, az ún. „vörös és fehér esztétikum” harmóniájára. Ezekben az esetekben kombinált terápia indokolt, mivel önmagában sem csak a sebészi, sem a csak restauratív terápia nem nyújt megfelelő eredményt. A komplex esetek eredményes ellátása érdekében sokszor gondos tervezésre és csapatmunkára van szükség; a protetikai és konzerváló fogászati ellátás mellett a kezelés sikerességéhez elengedhetetlen a parodontális sebészi beavatkozás is.

A kezelés megkezdése előtt fontos tisztázni, hogy reálisan milyen mértékben fogjuk tudni fedni a szabaddá vált fognyakat. Hiszen ennek megvannak a természetes anatómiai korlátai. Amennyiben az approximális csont is érintett (Miller III-IV), teljes recessziófedésre aligha számíthatunk [55]. Továbbá NCCL esetén, amenynyiben a kopás kiterjed a fogak koronai részére is, csak speciális grafikus módszerrel rekonstruálható a hajdan volt zománc-cement határ vonala [83, 62]. (2. kép)

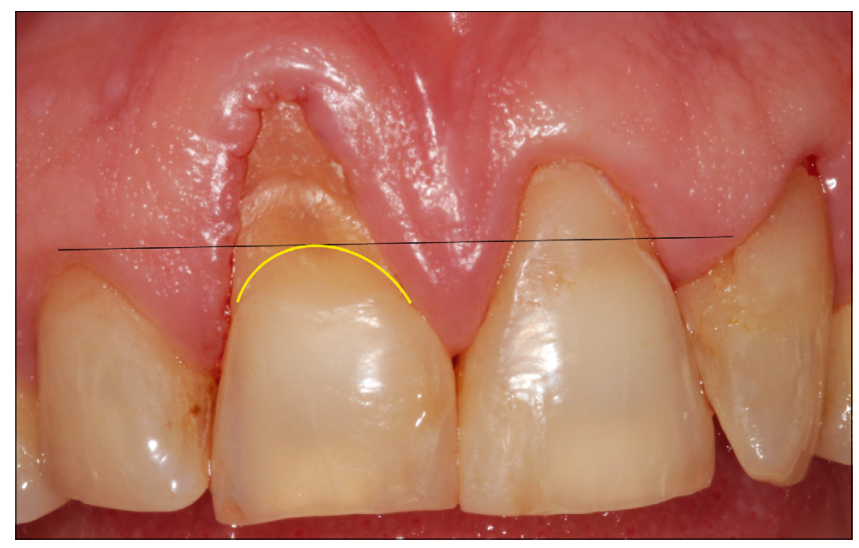

2. kép: Az anatómiai korona határának meghatározása Zucchelli és mts. által leírt módszer szerint 
llyenkor az eredmény elmarad az ép fogszövetviszonyok mellett végzett mukogingivális mútéti eredményekhez képest, ahol adott a pontos anatómiai referencia pont $[66,67]$.

Ha pusztán sebészi fedést alkalmazunk, az éles zománcszélek növelik a plakk-akkumuláció lehetőségét, illetve a hiányzó, vagy elvékonyodott zománc helyreállításának elmaradása esetén a fognyaki érzékenység megmaradhat. Ugyanakkor a restauratív kezelés önmagában nem vezet sikerre, hiszen a pusztán töméssel történő ellátás nem esztétikus, megnyúlt fogakhoz vezet, a harmonikus ínylefutás helyreállítása elmarad, és megfelelő szélességű keratinizált íny hiánya esetén az egyéni plakk-kontroll is nehezebb, fájdalmasabb, ami gingivitiszhez vezethet [73].

Az NCCL-val társuló ínyrecessziók ellátásában tehát optimális eredmény a kombinált parodontális esztétikai sebészeti és restauratív technikákkal érhető el. Az irodalomban néhány esettanulmány elkülönítve vizsgálta a kárieszes és a nem kárieszes léziók korrekciós eredményeit [31, 73, 74]. Az esztétikai igények fokozódásának köszönhetően az utóbbi évtizedben megszaporodtak az ezt tárgyaló esettanulmányok, amelyekben az NCCL-val társuló ínyrecessziós esetek kombinált sebészi és restauratív kezelésének terápiás technikáit és az elérhető eredményeket tárgyalják. Ezek többnyire csupán fél vagy egyéves eredményekről számolnak be $[3,48,49,65,66,67,25,21]$.

Az esztétikai-mukogingivális műtéti technikák palettája exponenciálisan szélesedik. Az ínyrecessziók korrekciójában ma a módosított koronálisan elcsúsztatott lebennyel (MCAF) kombinált szubepiteliális kötőszöveti graft (SCGT) az egyik legkiszámíthatóbb eredményt adó, ún. "gold standard" mukogingivális mútéti technika [80]. Irodalmi adatok szerint Miller I-II recessziók esetében NCCL hiányában, szerencsés anatómiai adottságok mellett átlagosan 97\%-os fognyaki fedés érhető el [63, 45, 60, 80]. Koronálisan elcsúsztatott lebeny (CAF) zománc mátrix derivátummal (EMD) vagy SCTG-tal kombinálva jobb eredményeket ad, javítja a biotípust és nagyobb százalékban eredményez teljes fognyaki fedést [13]. Más vizsgálatok szerint a CAF+EMD vagy $\mathrm{CAF}+\mathrm{SCTG}+\mathrm{EMD}$ nem eredményezett szignifikánsan jobb fognyaki fedést, mint a CAF önmagában, bár ezek szerint is az SCTG vagy EMD alkalmazása után javult az ínyszövet vastagsága, azaz a biotípus pozitív irányba módosult a kontroll oldalhoz viszonyítva $[7,56$, 51, 4].

Kombinált sebészi és restauratív kezelés esetén fontos eldönteni, hogy milyen időpontban és milyen tömőanyaggal célszerű a fognyaki tömést elvégezni [74]. Zucchelli és munkatársainak egyértelmú ajánlása, hogy a tömés előzze meg a sebészi kezelést [82]. Ennek egyik oka, hogy a mútét előtti állapotban könnyebben biztosítható a megfelelő izolálás, másrészt a helyreállított klinikai korona emergencia profilja is kedvez a későbbiekben elvégzett mútét során a gingiva kellő magasságban történő megtapadásának. A tömőanyag kiválasztása régóta foglalkoztatja a fogászati szakmát, elsősorban az elkészült fognyaki restaurátumok ínyszélre gyakorolt hatása miatt. Az ínygyulladás kialakulásának okai lehetnek a restaurátumok széli záródásának elégtelensége, a felszín durvasága, valamint a használt tömőanyag típusából adódó anyagtani tulajdonságok. A kompozíciós tömőanyagok esetén egyes szerzők a szubgingiválisan kiterjesztett tömések esetén fokozott szulkuszváladék-termelést vagy akár manifeszt ínyszéli gyulladást figyeltek meg $[77,71]$. Más vizsgálatok szerint a pontosan adaptált és megfelelően polírozott kompozit töméseknek nem volt káros hatása az ínyszélre [9].

In vitro és in vivo vizsgálatok szerint a rezin-üvegionomer tömőanyag számos tulajdonsága lehetővé teszi a tömőanyag szubgingivális alkalmazását [23, 72]. Az üvegionomer cementek (GIC) sikeres alkalmazását bemutató vizsgálati eredmények pontosan adaptált V. osztályú restaurációk esetén nem számoltak be ínygyulladásról [68, 27]. A szerzők véleménye szerint ez a GIC jó széli záródásának, valamint a fluoridleadásból eredő mérsékelt antibakteriális hatásnak köszönhető $[27,75]$. Hisztológiai vizsgálatok kimutatták, hogy mind a hámsejtek, mind a kötőszöveti fibroblasztok képesek tapadni a GIC felszínén [15, 23]. In vivo klinikai esetkontrollos közlemények számoltak be a GIC sikeres alkalmazásáról szubgingiválisan elhelyezkedő gyökérrezorbciók, vagy szubgingivális gyökérperforációk ellátásában [12, 76].

Az elmúlt évtizedben megjelent publikációk eredményei azt mutatják, hogy a kombinált terápia eredményei a gyökérfedés százalékos mértékében és a teljes gyökérfedés prevalenciájában összehasonlíthatók voltak a teljesen ép klinikai koronán végzett mútéti eredményekkel $[65,66,67]$. Egy randomizált, tükörszimmetrikus (split mouth) klinikai vizsgálatban a bilaterális Miller I ínyrecesszióval társuló NCCL esetében, CAF technikát alkalmazva, 6 hónappal a műtét után nem találtak különbséget a két oldal között a GIC töméssel ellátott és el nem látott fognyak esetében az íny állapotát és a fognyaki fedés mértékét illetően. Megállapításuk szerint a tömőanyag biokompatibilis volt. Egy másik vizsgálatban a bilaterális Miller I osztályú ínyrecesszióval társuló NCCL esetében, CAF+SCTG technikát alkalmazva, 6 hónappal a mútét után szintén nem talált különbséget a két oldal között a GIC töméssel ellátott és el nem látott fognyak esetében az íny állapotát és a fognyaki fedés mértékét illetően [67]. Mindkét közlemény felhívta a figyelmet az üvegionomer tömés széli adaptációjának és felületi simaságának fontosságára a posztoperatív eredmény sikerének és a plakkakkumuláció elkerülésének érdekében.

Klinikánk egy korábbi publikációjában, fognyaki restaurációk esetén egy új, fényre polimerizálódó nanotöltésű kompozit lakkal bevont üvegionomer tömés (Fuji IX GP Extra + G-Coat Plus - Equia ${ }^{\circledR} ;$ GC Europe) biokompatibilitási vizsgálatairól számoltunk be, két másik, hagyományos üvegionomer cementtel összehason- 
lítva. A vizsgálat szerint a fényre polimerizálódó, nanotöltésű lakkal bevont üvegionomer tömések gingivális hatása sem klinikailag, sem statisztikailag nem maradt el a kontrollokétól [37].

Jelen klinikai vizsgálatunk célja, hogy NCCL-val társuló Miller I-II típusú ínyrecessziók mútéti korrekciója során randomizált tükörszimmetrikus módszerrel megvizsgáljuk, hogy a nanotechnológiás polimer lakkal fedett GIC tömőanyag milyen sikerrel használható NCCL komplex sebészi-restauratív ellátásában. Továbbá vizsgáltuk, hogy az SCTG, illetve EMD használata módosít-e az eredményeken.

\section{Anyag módszer}

A vizsgálatot a Semmelweis Egyetem Regionális Kutatásetikai Bizottsága Engedélyével a Helsinki Deklarátum aktuális verziójának irányelvei szerint végeztük a Semmelweis Egyetem Parodontológiai Klinikáján. 20 parodontálisan egészséges, tükör-szimmetrikusan elhelyezkedő Miller I-Il típusú ínyrecesszióval és NCCL-val rendelkező pácienst válogattunk a vizsgálatba A beválogatás és kizárás kritériumait foglalja össze az 1. táblázat. Fő panaszként fognyaki érzékenység és/ vagy az ínyvisszahúzódás okozta esztétikai zavar szerepelt. A résztvevő páciensek írásos beleegyező nyilatkozatának birtokában előzetesen szupra/szubgingivalis depuráláson, valamint egyéni szájhigiéniás instruáláson estek át (a recesszióknál Roll-technika puha sörtéjü fogkefével, máshol módosított Bass-technika, valamint fogköztisztítók és fogselyem). A tömés elkészítése előtt az íny állapotát rögzítettük és digitális fotó készítésével dokumentáltuk.

Kiinduláskor a következő paramétereket mértük: az elsődleges paraméterek között szerepelt a recesszió mélysége (AGR), amelyet a zománc-cement határ és a marginális ínyszél között mértünk milliméter beosztású parodontális szondával (UNC-15), az ínyvérzési index (BOP) az érintett fog mellett midbukkálisan, valamint a szubjektív fognyaki érzékenység (DE), amelyet vizuális analóg skálán (VAS) a páciens értékelt 1-10-ig [1]. Amenynyiben a cervikális lézió ráterjedt a zománcra is, referenciapontként a zománc-cement határ nem használható. Ilyenkor a Zucchelli és mts. által leírt módszerrel állapítottuk meg az anatómiai korona virtuális határát, a páciens biotípusa és a környező fogak marginális gingiva lefutása alapján [83]. (2. kép) A pre- és posztoperatív méréseket kalibrált tapasztalt szakorvos (PZS) végezte.

A másodlagos vizsgálati paramé-

\section{Beválogatási és kizárási kritériumok}

1. Bilaterális szimmetrikus Miller Class I-II recesszió + cervikális, nem carieses maximum. 2-3 mm mély fognyaki kopás

2. Gyulladásmentes parodontium maximum. 20\% BOP érték (FMBS)

3. Plakkmentes állapot, maximum. 20\% teljes száj plakkérték (FMPS)

4. Egyébként egészséges 18-55 éves egyén

5. Nincs megelőző antibiotikus kezelés

6. Vitális fog, korábban nem volt tömés a fognyakon, nincs okklúziós trauma

7. Korábban még nem volt parodontális mukogingivális mútét

terek: az ínyrecesszió szélessége (IRSZ) a zománc-cement határ vonalában; a relatív ínyrecesszió (RGR) az ínyszél és az incizális él távolsága; a szondázási mélység (PD) az ínyszél és a tasakbázis távolsága; a klinikai tapadási nívó (CAL); a keratinizált íny szélessége (KISZ) az ínyszél és a mukogingivális junkció távolsága; az NCCL koronális és apikális széle közötti távolság (NCLM); a gyökérfelszínre eső nem NCCL magassága (NCLMG), a lézió apikális széle és a CEJ közötti távolság voltak. A keratinizált íny (KIV) vastagságát injekciós tű segítségével, a tű $2 \mathrm{~mm}$-es oliváját használva referenciaként ítéltük meg. A szulkuszváladékot (S-VÁL) a szulkuszba helyezett ISO 40-es papírpoénnal 30 másodperc alatt mért mennyisége $\mathrm{mm}$-ében határoztuk meg. (3., 4. kép)

A töméssel ellátandó felszínek kiválasztása elektronikus randomizációval történt. Ezt követően a teszt ol-

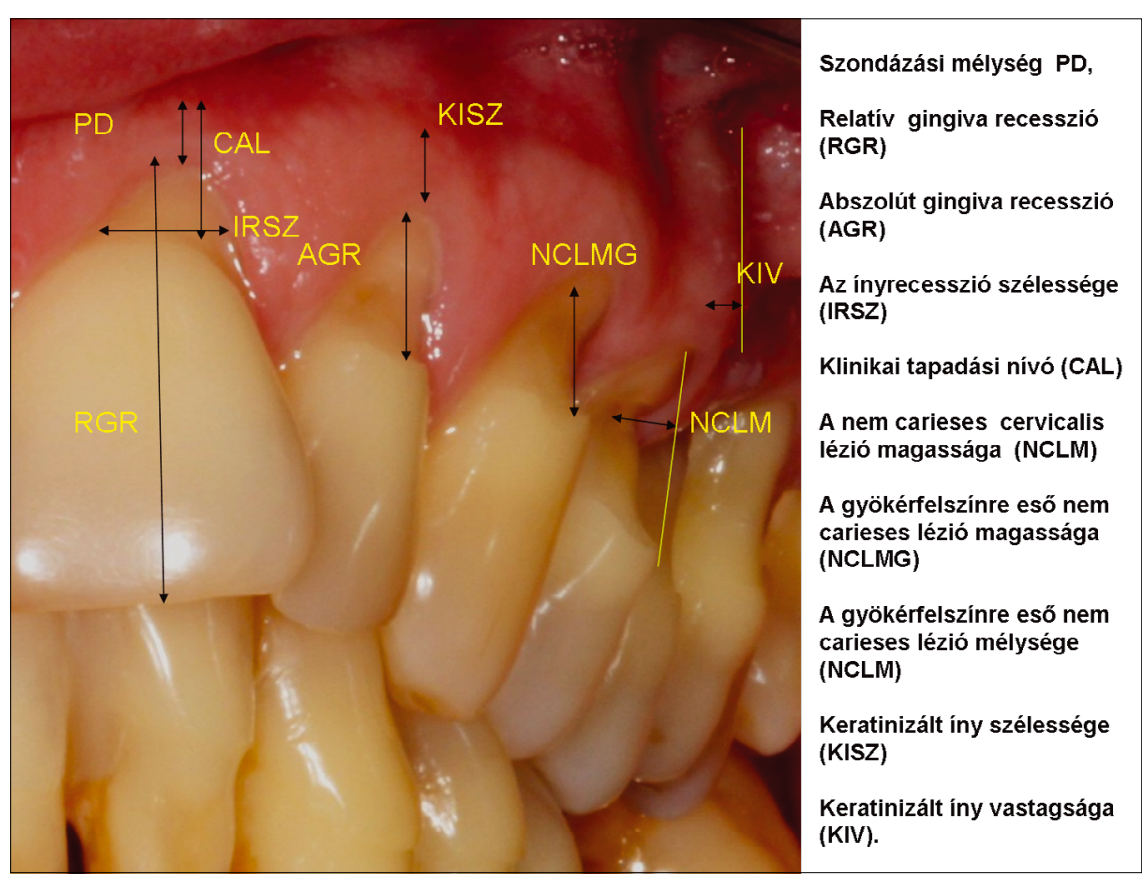

3. kép: Az elsődleges és másodlagos paraméterek meghatározásához használt mérőpontok 


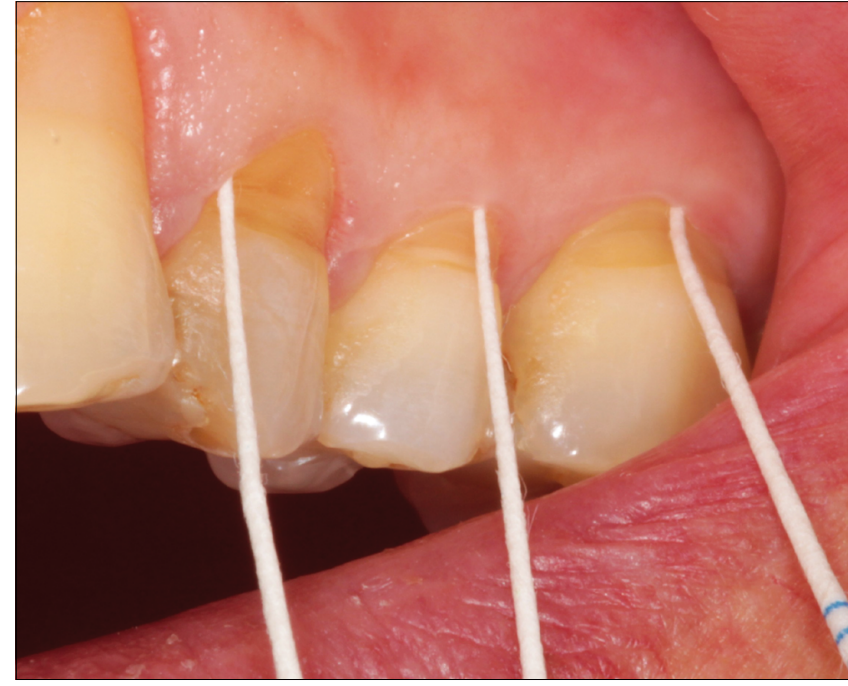

4. kép: A sulcusváladék maghatározása abszorbciós papírcsúcsokkal

dalon (T) a Miller I-II ínyrecessziót és ék alakú fognyaki kopást mutató fogak abradált dentin felszínét polírozó gyémántfúróval felfrissítettük, de makroretenciós Black V. osztályú kavitást nem preparáltunk. A dentinfelszín kondicionálása után egy újfajta üvegionomer cement Equia $^{\circledR}$ (GC Europe, Leuven, Belgium) került behelyezésre. Amennyiben a fognyaki kopás széle nem terjedt az ínyszél alá, kofferdám izolálást nem alkalmaztunk. Az ínyszélt nagyon megközelítő lézió vagy enyhén szubgingivális kavitás esetében a szulkuszba retrakciós fonalat helyeztünk. A töméseket kompozit tömőeszközökkel adaptáltuk és simítottuk el. A kész tömések finírozása, polírozása után, a gyártó által a tömőanyaghoz mellékelt, fényre polimerizálódó nanotöltésü lakkot (G-Coat Plus ${ }^{\circledR}$ GC Europe, Leuven, Belgium) alkalmaztunk. (5. kép)

A másik oldali, tükörszimmetrikus kontroll fognyaki lézió $(K)$ abradált dentin felszínét polírozó gyémántfúróval felfrissítettük, a zománcszéleket és a kavitás apikális éles szélét elsimítottuk, majd Gracey kürettel gyökérsimítást végeztünk. A parodontális paramétereket kiinduláskor és 6 hónap elteltével rögzítettük.

\section{Sebészi terápiás protokoll}

Premedikációként 2000 mg Amoxicillin+klavulánsav (Augmentin, Pfizer, Magyarország), valamint 400 mg Ibuprofen [41] kombinációját kapták a páciensek.

Mindkét oldalon módosított koronálisan elcsúsztatott lebenytechnikát (MCAF) alkalmaztunk [81]. További randomizáció alapján az egyik alcsoportban zománc mátrix derivátumot (MCAF-EMD), míg a másik alcsoportban szubepiteliális autológ kötőszöveti graftot (MCAF-SCTG) alkalmaztunk. (6. kép) A mútéteket egy tapasztalt szakorvos $(\mathrm{HA})$ végezte helyi érzéstelenítésben.

\section{A mútéti technikák röviden}

A. MCAF-EMD csoport: A szabaddá vált fognyakat mindkét oldalon Ethylen-diamin-tetra-acetat (EDTA, Prefgel, Straumann, Svájc) oldattal 120 mp-ig előkezeltük a cement/dentin felszín kondicionálására. Hlyi érzéstelenítésben a teszt- és a kontrollfog körül intraszulkuláris metszést ejtettünk, majd a fog két oldalán az interdentális papillát ferdén divergáló metszéssel félvastagon átmetszettük. Ezután apikális irányba teljes vastagságú lebenyt képeztünk, amit a mukogingivális határvonaltól apikálisan félvastagon tovább mobilizáltunk. Ezt követően a recipiens ínypapillák hámrétegét ferdén lemetszettük. A GIC-tel ellátott fognyakra (T) fecskendővel felvittük az EMD-t, majd az ínylebenyt a zománc-cement határtól $1 \mathrm{~mm}$-rel koronálisan pozicionáltuk és $6 / 0$ monofil varróanyaggal felfüggesztő és cirkumdentális öltésekkel rögzítettük. (6. kép)

B. MCAF-SCTG csoport: A recipens terület lebenyképzése megegyezik az előbbiekkel. A szájpadból single incision technikával [38] félvastag subepitheliális kötőszöveti lebenyt (SCTG) preparáltunk, majd a lebenyt módosított horizontális matracöltésekkel [10] zártuk. Az eltávolított kötőszöveti graftot két egyenlő részre osztottuk, majd mind a T és a K oldalon szorosan adaptáltuk a tömésre/fognyakra a zománc-cement határtól $1 \mathrm{~mm}$ rel koronálisan. Végül matracöltésekkel laterálisan rögzítettük. A lebenyt feszülésmentesen, koronálisan cirkumdentális és felfüggesztő öltésekkel $6 / 0$ monofil fonallal levarrtuk [80]. (6. kép)
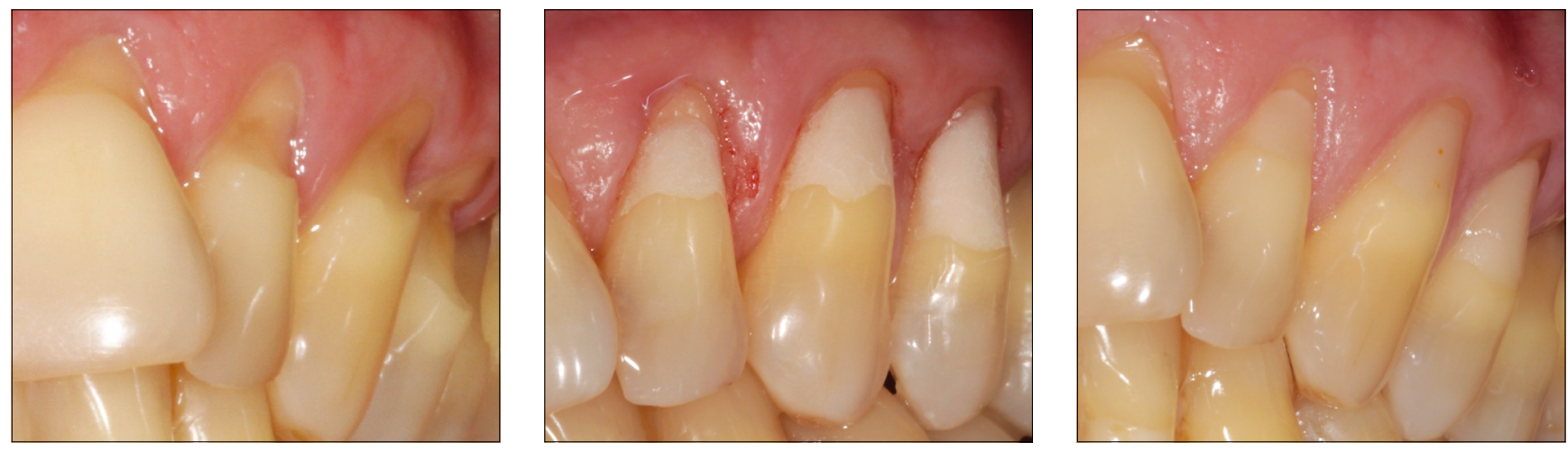

5. kép: Az NCCL lézió ellátása GC Equia® tömőanyaggal és a nanotöltésű lakk applikációja 


\section{Posztoperatív ellátás}

A műtétet követő héten $3 \times 625 \mathrm{mg}$ Augmentint, és szükség szerint diclofenac [59] tartalmú gyulladáscsökkentőt (Cataflam, Novartis, Magyarország) javasoltunk. A mütét területén a varratszedésig fogmosási tilalmat és $0,12 \%$-os chlorhexidines szájöblítőt rendeltünk el a pácienseknek (14 nap) naponta háromszor [58]. A mütét után a pácienseket először kéthetente, majd havonta kontrollra és szükség esetén szupragingivális tisztításra visszarendeltük, az eredményeket a 6 . hónapban kiértékeltük.

Az eredményeink statisztikai kiértékeléséhez átlag és szórásszámítást végeztünk. A szignifikancia értékelé-
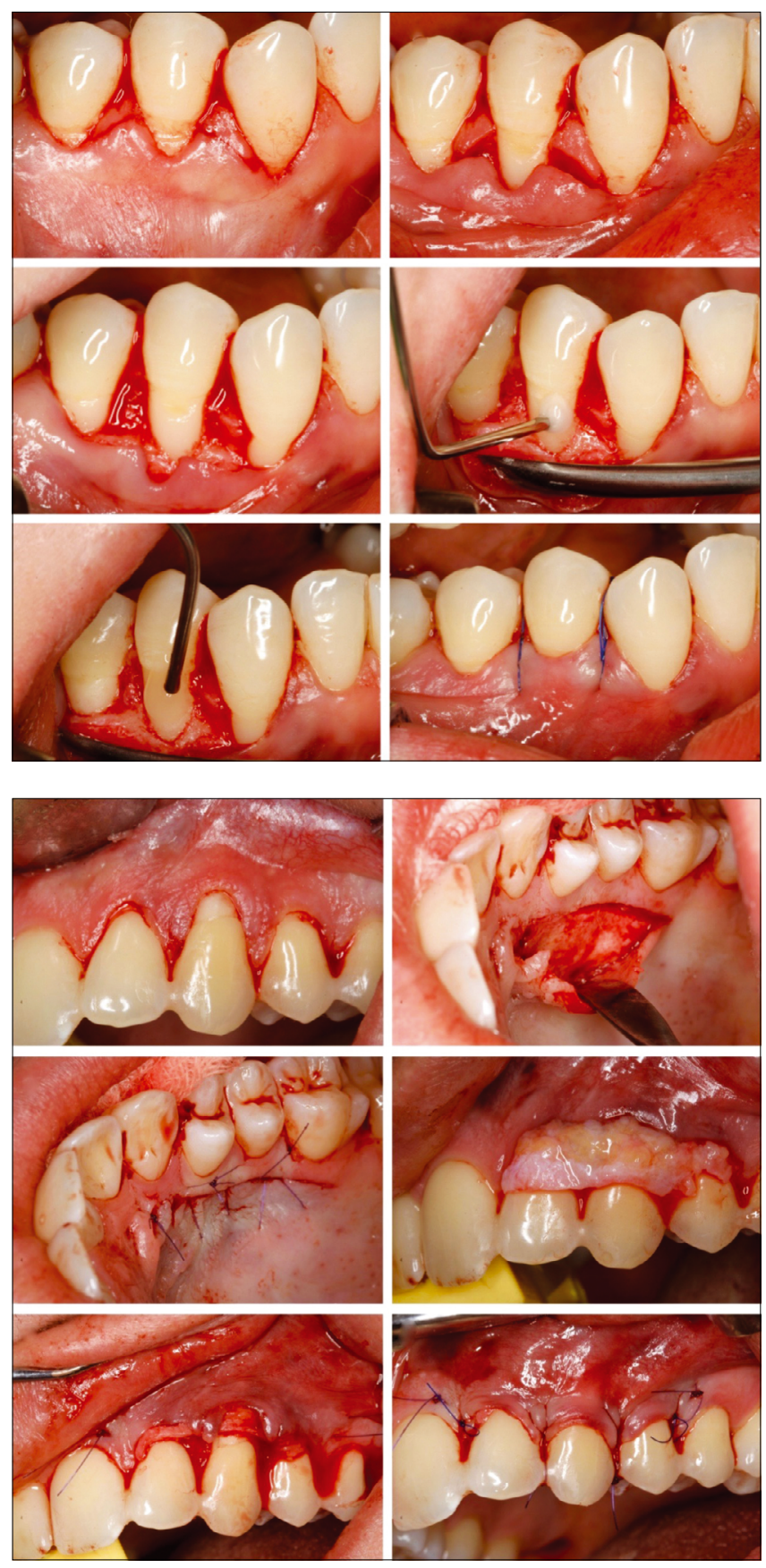

6. kép: MCAF+EMD és a MCAF+CTG sebészi technikák sére csoporton belül egymintás t-próbát, a csoportok összehasonlítására ANOVA-t használtunk. Statisztikai szignifikáns eltérést $(P<0,05)$ fogadtunk el.

\section{Eredmények}

A vizsgálatban 20 (11 nő és 9 férfi) 18-55 év közötti, teljesen ép, gyulladásmentes parodontiumú egyén vett részt. A demográfiai adatokat, a kiindulási plakk és vérzési értékeket, valamint a NCCL eloszlását a 2. táblázat foglalja össze. Összesen 6 pár szemfog, 12 pár kisőrlő és két pár első nagyőrlő fog került mútéti korrekcióra.

2. táblázat

A demográfiai adatok

és a kiindulási plakk- és ínyvérzési értékek

\begin{tabular}{|l|c|c|}
\hline & MCAF-EMD & MCAF-SCTG \\
\hline $\mathrm{n}$ & 10 & 10 \\
\hline Életkor (év) & & \\
Átlag \pm SD & $37,1 \pm 9,6$ & $31,9 \pm 9,1$ \\
Tartomány & $25-52$ & $21-52$ \\
\hline Nem (férfi/nő) & $3 / 7$ & $6 / 4$ \\
\hline Fogak [n (\%)] & & \\
Szemfog & $3(30)$ & $3(30)$ \\
Első premoláris & $6(60)$ & $6(60)$ \\
Első nagyőrlő & $1(10)$ & $1(10)$ \\
\hline FMPI (\%) & 17 & 15 \\
\hline FMBI (\%) & 10 & 9 \\
\hline
\end{tabular}

A mért keratinizált gingivavastagság (KIV) értékek szerint az MCAF csoportban hét páciens a vékony és három a normál biotípusba tartozott. Az MCAD+EMD csoportban nyolc páciens vékony, míg kettő páciens normál biotípust mutatott.

A preoperatív elsődleges és másodlagos parodontális paraméterek átlagértékeit foglalja össze a 3. táblázat 1.2. valamint 5.6. oszlopa.

Mindkét sebészi technika a teszt- és a kontrollfognál is statisztikailag szignifikánsan csökkentette a receszszió mélységét ( $A G R$ ) és szélességét (IRSZ), illetve javította a klinikai tapadási nívót $(\mathrm{CAL}){ }^{*}=\mathrm{p} \leq 0,05$. (3. táblázat 3.4. és 7.8. oszlopa és 7. kép)

Az eredmények szerint a fognyaki fedés mértéke közel megegyezett a teszt- és a kontroll oldalon, kivéve az MCAF+EMD csoportot, ahol a tesztoldal rosszabb posztoperatív eredményt mutatott. Az átlagos receszsziófedés értékeket foglalja össze a 4. táblázat. Látható, hogy hat hónappal a mútét után a tesztoldalon az EMD csoportban átlagosan csak $40,0 \pm 32,0 \%$, míg az SCTG esetében $76,92 \pm 19,23 \%$ volt a fognyaki fedés mértéke (statisztikailag szignifikáns különbség). Ezzel szemben ugyanezen értékek a kontroll oldalakon $66,66 \pm 35,0 \%$ és $73,07 \pm 21,93 \%$ voltak. A dentin-érzékenység minden csoportban csökkent a kiindulási értékekhez képest. Mindkét T, illetve az SCTG-tal kezelt 
A preoperatív és a 6 hónapos elsődleges és másodlagos parodontális paraméterek átlagértékei. Statisztikai szignifikáns eltérés $(P<0,05)$

\begin{tabular}{|c|c|c|c|c|c|c|c|c|}
\hline \multirow[t]{3}{*}{ Paraméterek } & \multicolumn{4}{|c|}{ MCAF-EMD } & \multicolumn{4}{|c|}{ MCAF-SCTG } \\
\hline & \multicolumn{2}{|c|}{ kiindulás } & \multirow{2}{*}{$\frac{6 \text { hónap }}{T}$} & \multirow[b]{2}{*}{ C } & \multicolumn{2}{|c|}{ kiindulás } & \multicolumn{2}{|c|}{6 hónap } \\
\hline & $T$ & $\mathrm{C}$ & & & $T$ & $\mathrm{C}$ & $T$ & $\mathrm{C}$ \\
\hline AGR (mm) & $2,5 \pm 0,8$ & $2,4 \pm 1$ & $1,5 \pm 1,27^{\star}$ & $0,8 \pm 0,8^{*}$ & $2,6 \pm 1,1$ & $2,6 \pm 1,2$ & $0,6 \pm 0,97^{*}$ & $0,7 \pm 1,2^{*}$ \\
\hline $\mathrm{DE}(0-10)$ & $3,7 \pm 2$ & $2,2 \pm 1,7$ & $1,8 \pm 1,5^{\star}$ & $1,9 \pm 1,2$ & $5,4 \pm 2,1$ & $4,6 \pm 2,1$ & $2,2 \pm 1,9^{\star}$ & $1,4 \pm 1,2^{*}$ \\
\hline $\mathrm{BOP}(0 / 1)$ & $0,1 \pm 0,3$ & $0,2 \pm 0,4$ & $0,3 \pm 0,5$ & $0 \pm 0$ & $0,1 \pm 0,3$ & $0,2 \pm 0,4$ & $0,5 \pm 0,5$ & $0,2 \pm 0,4$ \\
\hline IRSZ (mm) & $4 \pm 0,7$ & $3,8 \pm 0,6$ & $2,3 \pm 1,6^{*}$ & $1,9 \pm 1,79^{*}$ & $4,3 \pm 1,6$ & $3,9 \pm 1,6$ & $1,9 \pm 2,8^{*}$ & $1,6 \pm 2,67^{*}$ \\
\hline RGR (mm) & $12 \pm 1,3$ & $12 \pm 1,2$ & $11 \pm 1,6^{*}$ & $9,9 \pm 1,4^{*}$ & $11 \pm 1,3$ & $11 \pm 1,3$ & $9,4 \pm 1^{*}$ & $9,5 \pm 1,3^{*}$ \\
\hline PPD (mm) & $1,7 \pm 0,7$ & $1,6 \pm 0,5$ & $1,6 \pm 0,7$ & $1,4 \pm 0,5$ & $1,9 \pm 0,6$ & $1,7 \pm 0,5$ & $3 \pm 1,2$ & $1,9 \pm 0,6$ \\
\hline $\mathrm{CAL}(\mathrm{mm})$ & $4,2 \pm 1,2$ & $4 \pm 1,2$ & $3,1 \pm 1,52^{*}$ & $2,3 \pm 1,2^{*}$ & $4,5 \pm 1,3$ & $4,3 \pm 1,4$ & $3,6 \pm 1,17^{\star}$ & $2,6 \pm 1,3^{*}$ \\
\hline KISZ (mm) & $2,5 \pm 0,7$ & $2,5 \pm 0,8$ & $2,2 \pm 0,79$ & $2,6 \pm 0,69$ & $2,5 \pm 1,5$ & $2,1 \pm 1,6$ & $2,4 \pm 1,07$ & $2,2 \pm 1,39$ \\
\hline $\mathrm{KIV}(\mathrm{mm})$ & $1,2 \pm 0,4$ & $1,1 \pm 0,3$ & $1,2 \pm 0,42$ & $1 \pm 0$ & $1,2 \pm 0,4$ & $1,3 \pm 0,5$ & $1,5 \pm 0,53$ & $1,3 \pm 0,67$ \\
\hline S-VÁL (mm) & $2,3 \pm 0,9$ & $2 \pm 1,2$ & $1,3 \pm 0,7^{*}$ & $1,2 \pm 0,4$ & $1,3 \pm 0,5$ & $1,2 \pm 0,4$ & $1,4 \pm 0,5$ & $1,4 \pm 0,7$ \\
\hline NCLM (mm) & $3,2 \pm 1,2$ & $2,9 \pm 1,3$ & $2,2 \pm 1,4^{*}$ & $1,4 \pm 1,3^{*}$ & $2,8 \pm 1,4$ & $2,5 \pm 1,6$ & $1,4 \pm 1,6^{*}$ & $1,3 \pm 1,5^{\star}$ \\
\hline NCLMG (mm) & $2 \pm 0,9$ & $1,7 \pm 1,1$ & $1,2 \pm 1,3$ & $0,9 \pm 0,9^{*}$ & $2,1 \pm 1,4$ & $1,9 \pm 1,4$ & $0,6 \pm 1,1^{*}$ & $0,6 \pm 1,1^{*}$ \\
\hline
\end{tabular}

4. táblázat

Átlagos recessziófedés-értékek 6 hónappal a mútétek után

\begin{tabular}{|c|c|c|}
\hline & EMD & CTG \\
\hline T & $40,0 \pm 32,0 \%$ & $76,92 \pm 19,23 \%$ \\
\hline C & $66,66 \pm 35,0 \%$ & $73,07 \pm 21,93 \%$ \\
\hline
\end{tabular}

K csoportban a csökkenés statisztikailag szignifikáns volt, szemben az EMD-nal kezelt kontrollcsoporttal. A DE csökkenés az SCTG csoportban szignifikánsan magasabb volt az EMD csoporthoz képest. (7., 9. kép)

Hat hónappal a műtét után mindkét mütéti technika esetében a BOP értékek klinikailag jelentős, bár statisztikailag nem szignifikáns mértékben voltak magasabbak az SCTG-vel kezelt tesztoldali fogaknál, mint a töméssel el nem látott kontroll oldalon. (8. kép) Ugyanakkor, ha a teszt és a kontroll oldali BOP értékeket ha- sonlítottuk össze, ez már statisztikailag szignifikáns ( $p \leq 0,05$ ) különbséget hozott a tesztoldali fogak rovására. Az SCTG tesztoldali posztoperatív átlagos PD érték is jóval magasabb volt a bázisértékekhez viszonyítva, azonban ez nem volt szignifikáns. Az EMD és SCGT csoportokat összehasonlítva a PD szignifikáns emelkedést mutatott SCTG használata esetén.

\section{Megbeszélés}

Minden NCCL-val társuló ínyrecesszió sebészi korrekciós mútéteinek tervezésekor az első és legfontosabb lépés az oki tényezők feltárása (traumatizáló fogmosás, savas ételek, italok fogyasztása, parafunkciós szokások, traumás okklúzió, valamint a plakk-akkumuláció sebessége és mértéke), lehetőség szerinti eliminálása és a páciens fogmosási technikájának optimalizálása. Sok esetben a fognyaki kopással társuló Miller

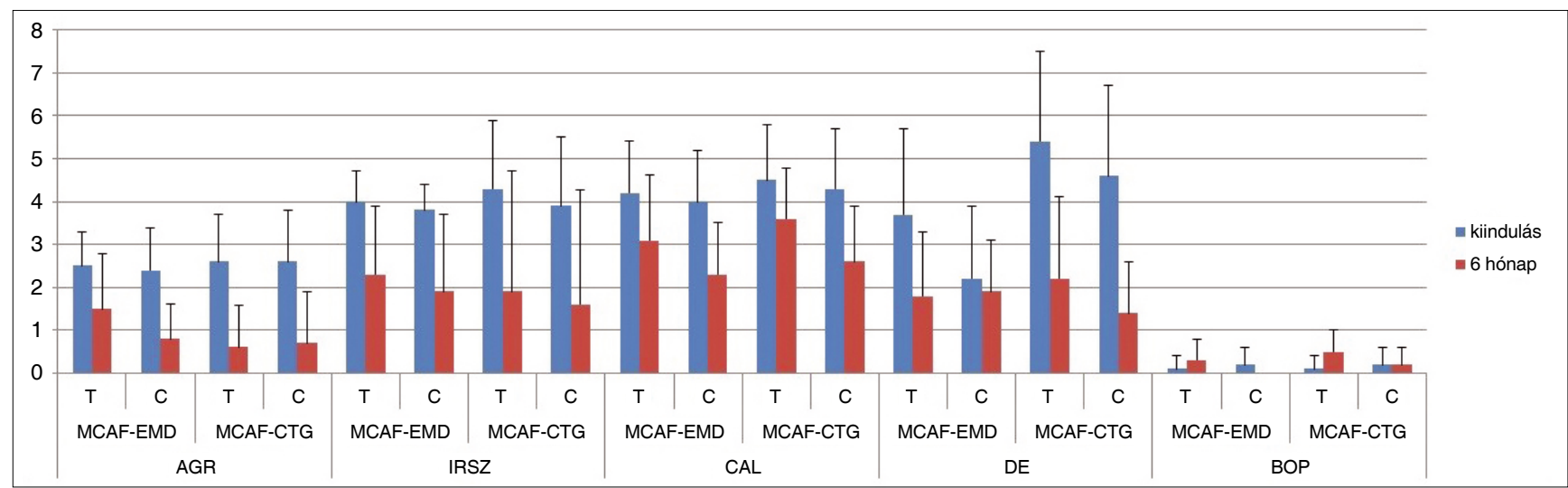

7. kép: Az ínyrecesszió mélysége (AGR), az ínyrecesszió szélessége (IRSZ), a klinikai tapadási nívó (CAL), a dentinérzékenység (DE) és az ínyvérzés (BOP) változása hat hónappal a mútét után 


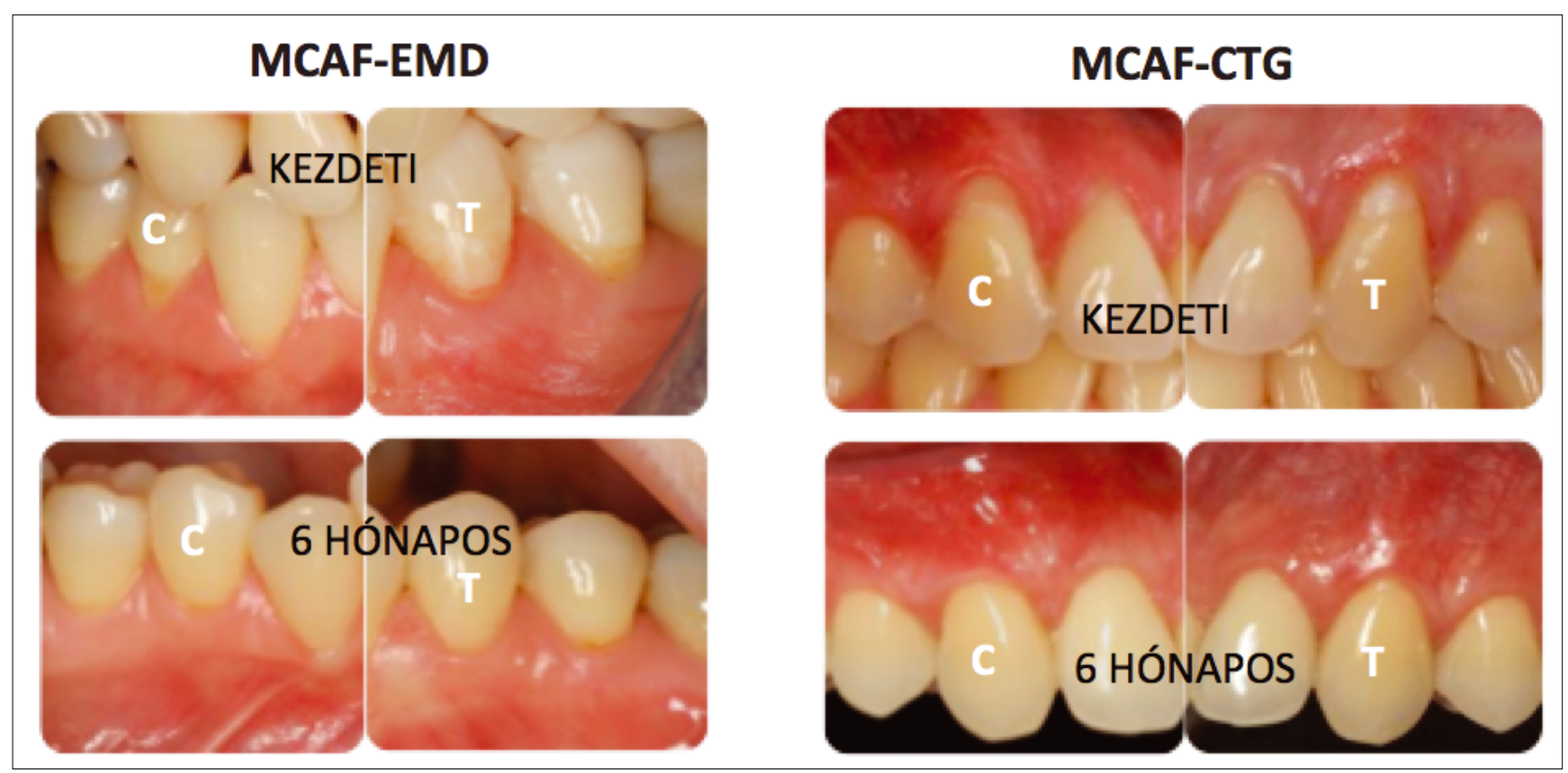

8. kép: Pre- és posztoperatív parodontális állapot a teszt és a kontroll oldalon a MCAF+EMD, valamint MCAF+CTG mütétek után.

I-II ínyrecesszió kombinált sebészi restauratív terápiát igényel $[80,65]$. Amennyiben a NCCL kezelése csupán restauratív, akkor sokszor kényszerülne a fogorvos koronahosszabbító mútétre a megfelelő izolálás érdekében, mivel a cervikális kopás apikális széle az esetek közel 40\%-ában az ínyszélnél, vagy az ínyszél alatt (32\%) van [54, 44]. Mindez további ínyrecesszióhoz vezethet. Ugyanakkor, mivel az esetek jelentős százalékában az NCCL érinti az anatómiai koronát is [8, 82], csupán mútéti korrekció mellett a fognyaki érzékenység megmaradhat, és az eredmény sem lenne esztétikailag kielégítő.

A kombinált terápia tervezésekor kérdéses az optimális tömőanyag kiválasztása. Az üvegionomer cementet a fogászatban közel négy évtizede használjuk [78, 52]. A restauratív fogászat már régóta sikeresen alkalmazza szubgingivális káriesz, gyökérrezorbció és endodontális gyökérperforációk kezelésében [12, 36]. Több vizsgálat szerint a GIC biokompatibilis, adhéziója sokkal jobb, mint a kompozitoké [11], mivel kémiailag kötődik a dentin felszínéhez, valamint folyamatosan fluorid ionokat ad le, amely tulajdonsága révén kárieszpreventív [70, 26]. Több szerző szerint a szubgingivális üvegionomer restaurátum körül nem volt emelkedett szulkuszváladék, vagy BOP-érték a szomszédos ép koronájú fogakhoz képest [23, 9, 11]. Egy bakteriológiai vizsgálat szerint a CAF lebeny alatt 6 hónappal a mútét után szubgingivális üvegionomer tömés felszínén a periodontopatogén baktériumok aránya és összetétele kedvezőbb volt, mint a kompoziton [68]. Ugyanakkor egyes klinikai vizsgálatok szerint az idősödő kompozit vagy GIC-tömések mellett fokozódik az ínygyulladási hajlam [75, 77].

Egyes vélemények szerint a mukogingivális mútét sikere kevésbé kiszámítható a restaurátummal fedett fognyakak mentén [61]. Ugyanakkor az NCCL-val társuló ínyrecessziók kezelésében több randomizált klinikai vizsgálat értékelte sikeresnek a szubgingivális GIC biokompatibilitását MCAF, illetve MCAF+SCTG mútétek után. A kombinált restauratív sebészi technikák között találunk az irodalomban MCAF [20, 36, 48, 66, 69], MCAF+SCTG [3, 67, 21], MCAF+kollagén xenograft [49] kombinált mútéteket. Egy tanulmány SCTG és GIC kombinált kezelés után hónapokkal az üvegionomer tömés felszínén klinikailag mérhető kúszó tapadásról számolt be [3]. In vitro vizsgálat hisztológiailag kimutatható kötőszövetes adaptációt és hámtapadást mutatott ki rezin üvegionomer felszínén [23]. Azonban humán vizsgálatokban nincs lehetőség a fognyaki adaptáció (reparáció) jellegének és minőségének szövettani értékelésére [66].

Az elmúlt évtizedben megjelent, NCCL-val társuló íny-

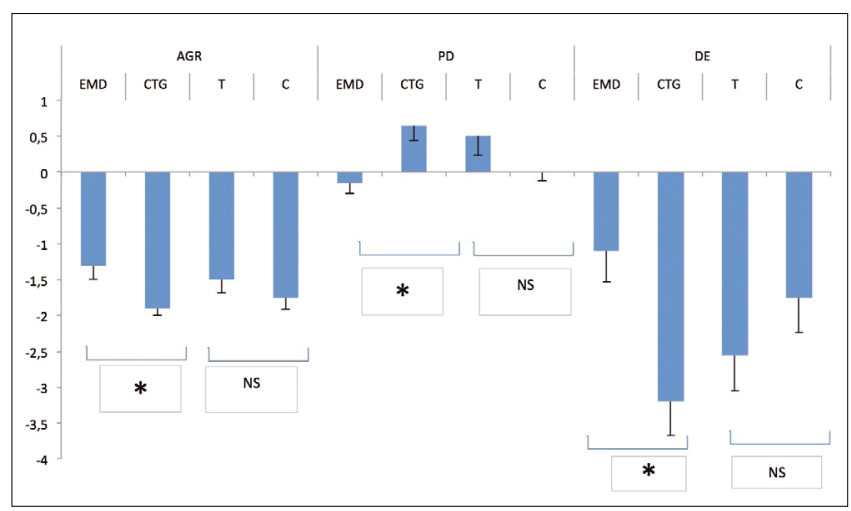

9. kép: Az abszolút gingivarecesszió (AGR), a szondázási mélység (PD) és a dentin érzékenység (DE) változások a bázis értékekhez viszonyítva 
recessziók sebészi korrekciós fél-, egyéves eredményei azt mutatják, hogy a restaurátummal kombinált mukogingivális sebészi eredmények akár a gyökérfedés százalékos mértékében, akár a teljes gyökérfedést adó esetek pervalenciájában összehasonlíthatók voltak a teljesen ép klinikai koronán végzett mukogingivális mútéti eredményekkel [65, 66, 67, 3, 20, 48]. A közlemények ugyanakkor felhívják a figyelmet az üvegionomer tömés széli adaptációjának és felületi simaságának fontosságára a posztoperatív eredmények és a plakk-kontroll érdekében [65].

$A z$ elmúlt években megjelent tanulmányok szerint a GC Equia ${ }^{\circledR}$; (GP Extra) és egy új, fényre polimerizálódó nanotöltésú kompozit fedőlakk (G-Coat Plus) javítja a tömés fizikai tulajdonságait, homogénebb és simább felszínt hoz lére, ami csökkenti a plakk-akkumuláció lehetőségét [22, 47]. Ezzel szemben egy 2015-ös vizsgálatunk szerint a nanotöltésü, fényre polimerizálódó lakkal bevont üvegionomer tömések gingivális hatása nem volt sem klinikailag, sem statisztikailag szignifikánsan jobb, mint a hagyományos resin módosított üvegionomer töméseké [37]. Ezért jelen vizsgálatunk célja volt tanulmányozni, hogy a nanotöltésú, fényre polimerizálódó lakkal bevont üvegionomer tömések mellett a NCCL-k milyen sikerrel korrigálhatók mukogingivális plasztikai mútétekkel.

Vizsgálatunkban a Zucchelli és munkatársa által leírt, módosított, koronálisan elcsúsztatott lebenytechnikát (MCAF) alkalmaztuk [81] az egyik alcsoportban EMD, a másikban pedig SCTG kombinációjával.

Számos vizsgálat mutatott rá a zománc-mátrix proteinek (EMD) [35] kedvező hatására recessziófedések esetén is, mert elősegíti a másodlagos cementképződést $[34,16,13]$. Mivel az EMD segíti a sérült gyökérfelszínen az appozicionális cementréteg képződését, lehetőség nyílik valódi kötőszöveti tapadás kifejlődésére. EMD alkalmazása nélkül nagyobb a valószínūsége, hogy a recessziófedés területén inkább hosszú hámtapadás alakul ki. Az EMD-nal végzett vizsgálati eredmények hosszabb távú stabilitását figyelték meg és vastagabb keratinizált szövet képződését írták le, szemben a koronális elcsúsztatás önáló alkalmazásával. Esetünkben a GIC felszínén az EMD másodlagos cement képzésében játszott szerepe eleve kizárható, azonban kíváncsiak voltunk arra, hogy számíthatunk-e a tömésre helyezett lebeny esetében is az EMD sebgyógyulásban kifejtett pozitív hatására a posztoperatív biotípus-változásban. Számos irodalmi adat utal arra, hogy SCTG alkalmazása előnyösen befolyásolja a recessziófedést [13]. Laza alveoláris nyálkahártya jelenlétében a lebeny alá helyezett, tömött rostos kötőszövet segít a lebeny stabilizálásában, a nyálkahártya jellegének, illetve biotípusának megváltoztatásában [42]. A nyálkahártya jellegének megváltoztatása, azaz a megfelelő mennyiségű feszes keratinizált íny megléte a parodontális egészség szempontjából kritikusnak túnik [28].

Zucchelli és munkatársainak ajánlása alapján SCTGtal kombinált mútét indikált a keratinizált gingiva hiá- nyában, prominens, vagy soron kívül álló fogak mellett, fognyaki kopások korrekciójában, protetikai restaurációk vagy implantációs fogpótlások esetén [80, 82]. A szerző kiemelte, hogy fognyaki kopások esetén SCTG hiányában a CAF a kopás szubgingivális konkáv felszínén kollabálhat, rontva a recessziófedés eredményességét.

A korábban idézett esettanulmányok mellett $[3,65$, $49,69,21,25,20]$ egy, a jelen vizsgálatunkhoz hasonló közleményt találtunk, ahol egyik oldalon CAF, a másik oldalon CAF+GIC mútétek után fél és két évvel értékelték eredményeiket. A féléves adatok szerint nem találtak szignifikáns különbséget a két oldal között, sem a fognyaki fedésben, recesszió-csökkenésben. sem pedig a gingiva állapotában (BOP, $\mathrm{PD}$ ). Hat hónappal a mútét után egyik esetben sem kaptak $100 \%$-os fognyaki fedést. A teljes NCCL fedés mértéke a tesztoldalon $51,57 \pm 17,2 \%$, a kontroll oldalon $53,87 \pm 12,6 \%$ CAF $(p>0,05)$. Egy közelmúltban megjelent csoport kontrollos vizsgálatában CAF technikával kezeltek ép koronájú fogakat, NCCL+resin módosított GIC és NCCL+mikrofil kompozit töméssel ellátott mútéti esetekben. Mindhárom esetben hasonló, 6 hónapos posztoperatív eredményeket kaptak, és a két különböző restaurátum mellett is hasonló, átlagosan $80 \%$-os fedést értek el [48].

Jelen klinikai vizsgálatunkban a GC Equia ${ }^{\circledR}$ töméssel helyreállított NCCL felett mindkét kombinált mukogingivális mútéti eredményekben a két oldal között nem volt szignifikáns különbség a recessziófedés tekintetében. Azonban az ínyrecesszió-csökkenés szignifikáns eltérést mutatott mind a teszt, mind a kontroll oldalon MCAF+SCTG csoport javára az MCAF+EMD csoporttal összehasonlítva. Ugyanakkor a recessziófedés mértékében nem volt szignifikáns különbség a $\mathrm{T}$ és a $\mathrm{K}$ csoportok között (3., 4. táblázat, 7. kép). Esetünkben hat hónappal a mútét után a teszt oldalon az EMD csoportban átlagosan csak 40,0 $\pm 32,0 \%$, míg az SCTG esetében $76,92 \pm 19,23 \%$ volt a fognyaki fedés. Ezzel szemben ugyanezen értékek a kontroll oldalakon 66,66 $\pm 35,0 \%$ és $73,07 \pm 21,93 \%$ voltak (4. táblázat). Ugyanakkor esetünkben a teszt oldalon (SCTG és EMD csoportban) a BOP és a reziduális $P D$ és $C A L$ értékek szignifikánsan magasabbak voltak, mint a kontroll oldaIon. (9., 10. kép) A hathónapos posztoperatív értékeléskor a fognyaki fedés mértékétől függetlenül a PD értékekben mindig nagyobb és ennek következtében kisebb klinikai tapadási nívó-nyereséget (CAL) mértünk a teszt oldalon, mint a töméssel nem korrigált NCCL oldalon. A CAL esetében ez a különbség statisztikailag szignifikáns volt. (9., 10. kép) Az EMD és SCTG csoport összehasonlításában a PD szignifikánsan nagyobb volt az SCTG csoportban, ami szignifikánsan magasabb szulkuszváladék-növekedéssel is társult, ami egyértelmúen gyulladásra utal.

Hat hónappal a mütét után az ínyszéli gyulladás foka (BOP) is szignifikánsan rosszabb értékeket mutatott a teszt oldalon. (9., 10. kép) Ez azt látszik igazolni, hogy a korábbi vizsgálatok eredményeitől eltérően a vizsgált nanotechnológiás lakkal fedett tömőanyag 


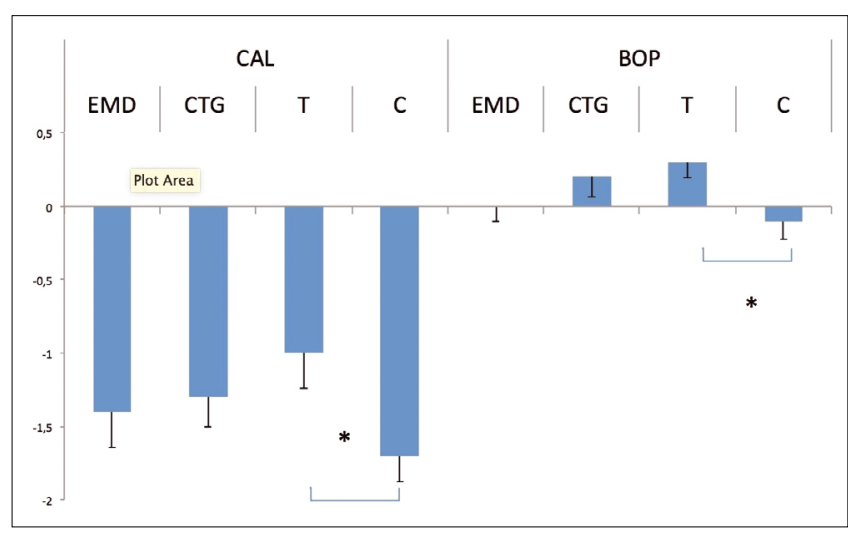

10. kép: A parodontális tapadási nívó (CAL)

és az ínyvérzés (BOP) változása a bázis értékekhez viszonyítva

nem segíti elő az ínyszövet adaptációját a fognyakhoz. Ez azt mutatja, hogy bár az SCTG javította a gingiva biotípusát és a fognyaki fedést, a tapadása azonban rosszabb volt a tömés felett, mint a gyökéren. Ennek egyik oka lehet a nantotechnológiás lakk (G-Coat Plus), amely megváltoztatta a GIC felszíni tulajdonságait és biokompatibilitását.

Ugyanakkor fontos kiemelni, hogy a fognyaki érzékenység SCTG alkalmazásakor T és $\mathrm{K}$ csoportban is szignifikánsan csökkent 6 hónap elteltével, az EMD csoportban viszont, csak a töméssel ellátott fogakon ( $\mathrm{T}$ ) volt szignifikáns a csökkenés. (9. kép)

Ma az NCCL esetében a kombinált restauratív és sebészi technikák abba az irányba mutatnak, hogy csupán az NCCL anatómiai koronára eső részét állítják helyre microfill kompozit töméssel, kialakítva olyan emergencia profilt, amely az implantátumokhoz hasonlóan kedvez a széles hámtapadás kialakulásának a gyökérfelszínen [21].

Összefoglalva megállapíthatjuk, hogy ínyrecesszió fedésére töméssel vagy tömés nélkül mindkét sebészi módszer alkalmas volt. A fognyaki érzékenység csökkentésére a módosított koronálisan elcsúsztatott lebeny (MCAF) még EMD-mal kiegészítve sem elegendő féléves időtávlatban. A vizsgált nanotöltésú polimer lakkal fedett üvegionomer tömőanyag alkalmazása bármelyik mútéti technika (MCAF-EMD vagy MCAF-SCTG) kiegészítéseként jelentősen csökkentette a fognyaki érzékenységet, ugyanakkor nagyobb szondázási tasakmélységet és magasabb átlagos ínyvérzési értékeket produkált.

\section{Klinikai jelentőség}

Az ínylebeny által nem fedhető, klinikai koronához tartozó fogfelszín töméssel történő ellátása jelentős mértékben csökkenti a fognyaki érzékenységet. Azonban a szubgingivális kiterjesztésú üvegionomer tömés nanotöltésủ lakkal fedve gátolja az ínyszövet letapadását, ínygyulladást és tasakképződést okozhat, ezért használata ott nem javallt. A gyökérfelszínre és koronai részre egyaránt kiterjedő NCCL esetén tehát a kombinált sebészi-restauratív technika alkalmazása javasolt, azaz a zománc-cement határ alatt ínylebennyel, afölött pedig a korona direkt felépítésével fedjük a léziót.

\section{Köszönetnyilvánítás}

A vizsgálatban nyújtott munkájáért köszönettel tartozunk Dr. Nevelits Annamáriának a statisztikai elemzésben, és az ábrák elkészítésében nyújtott nélkülözhetetlen segítségéért Dr. Lakatos Zsuzsanna biofizikusnak.

A vizsgálat a TAMOP 2.4.1.1.BO9/1/KMR/2010-0001 támogatásával jött létre.

\section{Irodalom}

1. AITKEN RC: Measurement of feelings using visual analogue scales. Proc R Soc Med. 1969; 62. (10): 989-93.

2. Albandar JM, Kingman A: Gingival recession, gingival bleeding, and dental calculus in adults 30 years of age and older in the United States, 1988-1994. J Periodontol. 1999; 70: 30-43.

3. Alkan A, Keskiner I, Yuzbasioglu E: Connective tissue grafting on resin ionomer in localized gingival recession. J Periodontol 2006; 77: 1446-1451.

4. Aroca S, Keglevich T, Nikolidakis D, Gera I, Nagy K, Azzi R, ETIENNE D: Treatment of class III multiple gingival recessions: a randomized-clinical trial. J Clin Periodontol 2010; 37: 88-97.

5. BARTLETT DW, ShAH P: A critical review of non-carious cervical (wear) lesions and the role of abfraction, erosion and abrasion. J Dent Res 2006; 85: 306-321.

6. Berlucchi I, Francetti L, Del Fabbro M, Basso M, Weinstein RL: The influence of anatomical features on the outcome of gingival recessions treated with coronally advanced flap and enamel matrix derivative: a 1-year prospective study. J Periodontol. 2005 Jun; 76. (6): 899-907.

7. Berlucchi I, francetti L, Del fabbro M, Testori T, Weinstein Rl: Enamel matrix proteins (Emdogain) in combination with coronally advanced flap or subepithelial connective tissue graft in the treatment of shallow gingival recessions. Int $J$ Periodontics Restorative Dent. 2002 Dec; 22. (6): 583-93.

8. Bhusari P, Agrawal N, Upadhyay S, Verma S, Jain A, Jaroli S: Classification \& prevalence of dental surface defects in areas of gingival recession a clinical study. J Clin Diagn Res. 2014 Jul; 8. (7)

9. Blank LW, Caresse RG, Charbeneau GT: The gingival response to well finished composite resin restorations. J Prosthet Dent. 1979; 42: 626-632.

10. Borghetti A, Monnet-Cortı V: La greffe de tissu conjonctif: indications et prélèvement. Chirurgie plastique parodontale. V. Editors. Edition CdP, Rueil-Malmaison, France, 2000; 193-208.

11. Brackett WW, Dib A, Brackett MG, Reyes AA, Estrada BE: Twoyear clinical performance of class $V$ resin modified glass ionomer and resin composite restoration. Oper Dent. 2003; 28: 477-481.

12. Breault LG, Fowler EB, Primack PD. Endodontic perforation repair with resin-ionomer: A case report. $J$ Contemp Dent Pract. 2000; 1: 48-59.

13. Cairo F, Nieri M, Pagliaro U: Efficacy of periodontal plastic surgery procedures in the treatment of localized facial gingival recessions. A systematic review. J Clin Periodontol. 2014; 15: 44-62.

14. Cairo F, Pagliaro U, Nieri M: Treatment of gingival recession with coronally advanced flap procedures: a systematic review. J Clin Periodontol. 2008; 35. (Suppl. 8): 136-162.

15. Camp MA, Jeansonne BG, Lallier T: Adhesion of human fibroblasts to root-end-filling materials. J Endod. 2003 Sep; 29. (9): 602-607. 
16. Castellanos A, de la Rosa M, de la Garza M, Caffesse RG: Enamel matrix derivative and coronal flaps to cover marginal tissue recessions. J Periodontol. 2006; 77: 7-14.

17. Ceruti P, Menicucci G, Mariani GD, Pittoni D, Gassino G: Non carious cervical lesions. A review. Minerva Stomatol. 2006; 55: 43-57.

18. ChAN DC, AdKINS J: Technique on restoring subgingival cervical lesion. Oper Dent. 2003; 29: 350-353.

19. Chrysanthakopoulos NA: Gingival recession: Prevalence and risk indicators among young greek adults. J Clin Exp Dent. 2014; 6 243-249.

20. CorsalR A: Root coverage of a previously restored tooth. A case report with a 7-year follow-up. Clin Cosmet Investig Dent. 2009 Jun. 18; 1: 35-38. Print 2009.

21. Deliberador tM, Martins tM, Furlaneto FA, Klingenfuss $M$ Bosco AF: Use of the connective tissue graft for the coverage of composite resin-restored root surfaces in maxillary central incisors. Quintessence Int. 2012; 43: 597-602.

22. Diam VTK, Tyas MJ, Ngo HC, Phuong LH, Khanh ND: The effect of a nano-filled resin coating on the 3-year clinical performance of a conventional high-viscosity glass-ionomer cement. Clin Oral Invest. 2014; 18: 753-759.

23. Dragoo MR: Resin-ionomer and hybrid-ionomer cements: Part II human clinical and histologic wound healing responses in specific periodontal lesions. Int J Periodontics Restorative Dent. 1997; 17: 75-87.

24. Dyer D, Addy M, Newcombe RG: Studies in vitro of abrasion by different manual toothbrush heads and a standard toothpaste. J Clin Periodontol. 2000; 27: 99-103.

25. EfeoĞlu A, Hanzade M, Sari E, Alpay H, Karakaş O, Koray F Combined periodontal and restorative approach to the treatment of gingival recessions with noncarious cervical lesions: a case treated with acellular dermal matrix allograft and compomer restorations. Int J Periodontics Restorative Dent. 2012 Aug; 32. (4): 441-448.

26. EL MaLlaKh BF, SARKAR NK: Fluoride release from glassionome cements in de-ionized water and artificial saliva. Dent Mater. 1990; 6: 118-122.

27. Francisconi LF, Scaffa PM, De Barros VR, Coutinho M, FrancisCONI PA: Glass ionomer cements and their role in the restoration of non-carious cervical lesions: Review J Appl Oral Sci. 2009; 17: 364-369.

28. Friedman N, Levine HL: Mucogingival surgery: Current status J Periodontol. 1964; 35: 5-21.

29. Garguilo AW, Wentz FM, Orban B: Dimensions and relations of the dentogingival junction in humans. J Periodontol. 1961; 32 261-267.

30. Gera I (szerk.): Parodontológia, II. kiadás Semmelweis Kiadó 2009. 7. fejezet 149-201.

31. Goldstein M, Nasatzky E, Goultschin J, Boyan BD, Schwartz Z Coverage of previously carious roots is as predictable a procedure as coverage of intact roots. J Periodontol 2002; 73: 1419-1426.

32. Grippo JO, Simring M, Coleman TA: Abfraction, Abrasion, Biocorrosion, and the Enigma of Noncarious Cervical Lesions: A 20-Year Perspective. J Esthet Restor Dent. 2012; 24: 10-25.

33. Grippo JO: Abfractions: A new classification of hard tissue lesions of teeth. J Esthet Dent. 1991; 3: 14-19.

34. Hägewald S, Spahr A, Rompola E, Haller B, Heijl L, Bernimoulin J-P: Comparative study of Emdogain and coronally advanced flap technique in the treatment of human gingival recessions. A prospective controlled clinical study. J Clin Periodontol 2002 29: 35-41.

35. Hammarström L, HeiJl L, Gestrelius S: Periodontal regeneration in a buccal dehiscence model in monkeys after application of enamel matrix proteins. J Clin Periodontol. 1997; 24: 669-677.

36. HARRIS RJ: Treatment of a cracked tooth with a resinionomer restoration and a connective tissue graft: A case report. Int J Periodontics Restorative Dent. 2000; 20: 612-617.

37. Horváth A, Papp Zs, Dobó-Nagy Cs, Gera I: GC Fuji IX GP, Fuji IX GP Extra és GC EQUIA üvegionomer tömőanyagok gingiva állapotára gyakorolt hatásának vizsgálata. Fogorv Szle. 2014; 125-130.

38. Hürzeler MB, Weng D: A single-incision technique to harvest subepithelial connective tissue grafts from the palate. Int J Periodontics Restorative Dent. 1999; 19. (3): 279-287.

39. IMFELD T: Dental erosion. Definition, classification and links. Eur J Oral Sci. 1996; 104: 151-155.

40 JÁsz M., VARGA G., Tóth Zs: Destruktív és protektív tényezők szerepe a fogkopások kialakulásában. Fogorv Sz. 2006; 99. évf. 6. sz. 223-230.

41. Jeske A., ZAHRowsKI J: Good evidence supports ibuprofen as an effective and safe analgesic for postoperative pain. J Am Dent Assoc. 2010; 141. (5): 567-568.

42. KaRRING T, LANG NP, LöE H: The role of gingival connective tissue in determining epithelial differentiation. J Periodontal Res. 1975; 10. (1): 1-11.

43. Kassab MM, Cohen RE: The etiology and prevalence of gingival recession. J Am Dent Assoc. 2003; 134: 220-225.

44. Lambrechts $P$, Van Meerbeek B, Perdigao J, Gladys S, Braem M, VANHERLE G: Restorative therapy for erosive lesions. Eur J Oral Sci. 1996; 104: 229-240.

45. LANGER B, LANGER L: Subepithelial connective tissue graft technique for root coverage. J Periodontol. 1985; 56: 715-720.

46. LARATO DC: Effects of artifical crown margin extension and tooth brushing frequency on gingival pocket depth. J Prosthet Dent. 1975 Dec; 34. (6): 640-643.

47. Lohbauer U, Krämer N, Siedschlag G és mtsai: Strength and wear resistance of a dental glass-ionomer cement with a novel nanofilled resin coating. Am J Dent. 2011; 24: 124-128.

48. Lucchesi JA, Santos VR, Amaral CM, Peruzzo DC, Duarte PM: Coronally positioned flap for treatment of restored root surfaces: a 6-month clinical evaluation. J Periodontol. 2007. Apr; 78. (4): $615-623$.

49. Martiniello N, Stefanini M, Zucchelli G: Full-mouth treatment of gingival recessions and noncarious cervical lesions with coronally advanced flap and xenogeneic collagen matrix: A 2-year case report. Int J Esthet Dent. 2016; 11. (4): 506-518.

50. Matis BA, Cochran MA: Technique on restoring cervical lesions. Oper Dent. 2002; 27: 525-527.

51. McGuIRE MK, NunN M: Evaluation of human recession defects treated with coronally advanced flaps and either enamel matrix derivative or connective tissue. Part 1: Comparison of clinical parameters. J Periodontol. 2003 Aug; 74. (8): 1110-1025.

52. McLeAN JW: Glass-ionomer cements. Br Dent J 1988; 164: 293-300.

53. Meurman JH, Ten Cate JM: Pathogenesis and modifying factors of dental erosion. Eur J Oral Sci. 1996; 104: 199-206.

54. Miller N, Penaud J, Ambrosini P, Bisson-Boutelliez C, Briancon S: Analysis of etiologic factors and periodontal conditions involved with 309 abfractions. J Clin Periodontol. 2003; 30: 828-832.

55. MILLER PD JR.: A classification of marginal tissue recession. Int J Periodont Restor Dent.1985; 5: 9-13.

56. Modica F, Del Pizzo M, Roccuzzo M, Romagnoli R: Coronally advanced flap for the treatment of buccal gingival recessions with and without enamel matrix derivative. A split-mouth study. J Periodontol. 2000 Nov; 71. (11): 1693-1698.

57. Mythri S, Arunkumar SM, Hegde S, Rajesh SK, Munaz M, Ashwin D: Etiology and occurrence of gingival recession - An epidemiological study. J Indian Soc Periodontol. 2015; 19: 671-675.

58. Newman MG, Sanz M, Nachnani S, Saltini C, and Anderson L: Effect of $0,12 \%$ Chlorhexidine on Bacterial Recolonization Following Periodontal Surgery. J Periodontol 1989; 60: 577-581.

59. Ong CK, Seymour RA: An evidence-based update of the use of analgesics in dentistry. Periodontol 2000. 2008; 46: 143-164.

60. Paolantonio M, di Murro C, Cattabriga A, Cattabriga M. Subpedicle connective tissue graft versus free gingival graft in the coverage of exposed root surfaces. A 5-year clinical study. J Clin Periodontol. 1997; 24: 51-56.

61. Pini Prato G, Tinti C, Vincenzi G, Magnani C, Cortellini P, ClausER C: Guided tissue regeneration versus mucogingival surgery in 
the treatment of human buccal gingival recession. $J$ Periodontol. 1992; 63: 919-928.

62. Pini-Prato GP, Franceschi D, Cairp F: Classification of dental surface defects in areas of gingival recession. $J$ Periodontol 2010; 81: 885-890.

63. RAETZKE PB: Covering localized areas of root exposure employing the "envelope" technique. J Periodontol 1985; 56: 397-402.

64. Sangnes G, Guermo P: Prevalence of oral soft and hard tissue lesions related to mechanical toothcleansing procedures. Community Dent Oral Epidemiol. 1976; 4: 77-83.

65. Santamaria MP, Suaid FF, Nociti Jr FP et al.: Periodontal Surgery and Glass lonomer Restoration in the Treatment of Gingival Recession Associated With a Non-Carious Cervical Lesion: Report of Three Cases. J Periodontol 2007; 78: 1146-1153.

66 Santamaria, MP, Suaid FF, Casati MZ, Nociti Jr FH, Sallum AW, Saltum EA:. Coronally Positioned Flap plus Resin-Modified Glass Ionomer Restoration for the Treatment of Gingival Recession Associated With Non-Carious Cervical Lesions: A Randomized Controlled Clinical Trial. J Periodontol. 2008; 79: 621-628.

67. Santamaria MP, ambrosano GMB, Casati MZ, Nociti Junior FH Sallum AW AND Sallum EA: Connective tissue graft plus resin-modified glass ionomer restoration for the treatment of gingival recession associated with non-carious cervical lesion: a randomizedcontrolled clinical trial. J Clin Periodontol. 2009; 36: 791-798.

68. Santos VR, Lucchesi JA, Cortelli SC, Amaral CM, Feres M, DuARTE PM: Effects of glass ionomer and microfilled composite subgingival restorations on periodontal tissue and subgingival biofilm: a 6-month evaluation. J Periodontol. 2007; 78: 1522-1528.

69. Santos FR, Storrer CL, Cunha EJ, Ulbrich LM, Lopez CA, DelibERADOR TM: Comparison of conventional and semilunar coronally positioned flap techniques for root coverage in teeth with cervical abrasion restored with pink resin. Clin Cosmet Investig Dent. 2017 Mar 9; 9: 7-11.

70. Sasanaluckit P, Albustany KR, Doherty PJ, Williams DF: Biocompatibility of glass ionomer cements. Biomaterials. 1993; 14: 906-916.

71. Schatzle M, Land NP, Anerud A, Boysen H, Burgin W, Loe H: The influence of margins of restorations of the periodontal tissues over 26 years. J Clin Periodontol. 2001; 28: 57-64.

72. Scherer W, Dragoo MR: New subgingival restorative procedures with Geristore resin ionomer. Pract Periodontics Aesthet Dent. 1995; 7: 1-4.

73. Terry DA, McGuire MK, McLaren E, Fulton R, Swift EJ Jr.: Perioesthetic approach to the diagnosis and treatment of carious and noncarious cervical lesions: Part I. J Esthet Restor Dent. 2003; 15. (5): 217-232.

74. Terry DA, McGuire MK, McLaren E, Fulton R, Swift EJ Jr.: Perioesthetic approach to the diagnosis and treatment of carious and noncarious cervical lesions: Part II. J Esthet Restor Dent. 2003; 15. (5): 284-296.

75. VAN DIJKEN JW, SJÖSTRÖM S: Development of gingivitis around aged restorations of resin-modified glass ionomer cement, polyacid-modified resin composite (compomer) and resin composite. Clin Oral Investig. 1998; 2: 180-183.

76. WHITE C JR.: Repair of a root resorption lesion. A case report. J Periodontol. 1998; 69: 596-600.

77. Willershausen B, Kottgen C, Ernst C P: The influence of restorative materials on marginal gingiva. Eur $J$ of Med Res. 2001; 6: 433-439.

78. WILSON AD, KENT BE: A new translucent cement for dentistry. The glass ionomer cement. Br Dent J. 1972; 132: 133-135.

79. Wood I, Jawad Z, Paisley C, Brunton P: Non-carious cervical tooth surface loss: a literature review. J Den. 2008; 36: 759-766.

80. ZUCCHELLI G: Mucogingival Esthetic Surgery, Quintessence (2013)

81. Zucchelli G, De Sanctis M: Treatment of Multiple Recession-Type Defects in Patients With Esthetic Demands. J Periodontol. 2000; 71: 1506-1514.

82. Zucchelli G, Gori G, Mele M, Stefanini M, Mazzotti C, Marzadori M, Montebugnoli L, De Sanctis M: Non-carious cervical lesions associated with gingival recessions: A decision-making process. J Periodontol. 2011; 82. (12): 1713-1724.

83. Zucchelli G, Testori T, De Sanctis M: Clinical and anatomical factors limiting treatment outcomes of gingival recession: A new method to predetermine the line of root coverage. J Periodontol, 2006; 77: 714-721.

\section{Mentesülnek a tagdíjfizetés alól a 70 évet betöltött MFE tagok}

2017. szeptember 28-án elnökségi ülés keretén belül a 2017/9/10. számú határozatban döntött az MFE elnöksége arról, hogy a hetvenedik életévüket betöltött MFE-tagok 70. születésnapjuk évét követő évtől kezdve mentesülnek a tagdíffizetési kötelezettség alól.

Mivel tagjainkról vezetett adatbázisunk a születési dátumot nem tartalmazza, így fontos, hogy érintett tagjaink, ha betöltötték a 70. életévüket, jelezzék azt a 06-70/9407798-as telefonszámon, az info@ mfe-hda.hu e-mailcímen vagy a Dugonics tér 13. 6720 Szeged címre írott levélben. Csak ennek bejelentése után tudjuk biztosítani, hogy a tagdíjfizetés elmaradása esetén is postázzuk a Fogorvosi Szemlét.

Tehát kérjük az 1947-ben vagy korábban született tagjainkat, jelezzék nekünk a fenti módon életkorukat, hogy tiszteleghessünk életpályájuk előtt azzal, hogy eltekintünk tagdíjuktól.

További jó egészséget kívánunk! 


\section{Papp Zs, Gera I, ERdős Zs, Horváth A} The combined surgical-restaurative correction of Miller I-Il gingival recessions associated with
non-carious cervical lesions - a randomized controlled clinical study - 6 months results

Background: The aim of this randomized split mouth clinical study was to evaluate the treatment of gingival recession, associated with non-carious cervical lesions (NCCL) by modified coronally advanced flap (MCAF) combined either with a subepithelial connective tissue graft (SCTG) or enamel matrix derivative (EMD) on the control sites, or in combination with a novel resin-modified glass ionomer restoration on the test sites.

Materials and Methods: Twenty patients presenting forty symmetric Miller Class I/II buccal gingival recessions, associated with NCCL, were included in the study. The NCCL on one side was randomly selected for restorative therapy by a nanofilled resin coated glass ionomer cement (GIC) (Equia®, GC) (test; T), while the other side was untreated (control; C). Both sites were further randomly assigned either to receive MCAF+SCTG or MCAF+EMD surgery. Absolute (AGR) and relative (RGR) gingival recession, clinical attachment level (CAL) and cervical lesion height (CLH) and width (CLW) probing pocket depth (PPD), bleeding on probing (BOP) and dentin hypersensitivity (DH) were measured at baseline and 6 months after treatment.

Results: Both surgical techniques both on the test and control sites resulted in statistically significant $(p<0,05)$ reduction of NCCL, AGR, GRW, gains in CAL and soft tissue coverage. The differences between groups were not statistically significant in the magnitude of soft tissue coverage with the exemption of MCAF+EMD group where the average coverage was significantly less compared to the other three subgroups. The percentages of covered CLH on the test sites were $40,0 \pm 32,0 \%$ for EMD, while $76,92 \pm 19,23 \%$ for the SCTG subgroup. On the contrary, there was no significant difference on the control sites treated either with $\operatorname{EMD}(66,66 \pm 35,0 \%)$ or SCTG $(73,07 \pm 21,93 \%)$. on the test sites treated with SCTG. The mean BOP scores showed statistically significant increase in the $T$ comparing to $C$ sites. The average postoperative PPD scores were clinically but not statistically higher $(p=0,057)$ on the $T$ compared to the $C$ sites, while SCTG treated groups showed statistically significantly higher scores compared to EMD groups. DH decreased statistical significantly on T and C sites in SCTG group and T sites in EMD group, but the decrease at the C sites of EMD group was not statistically significant.

Conclusion: Within the limits of the present study, it can be concluded that both surgical procedures provide comparable soft tissue coverage both on the test sites filled with GIC and also on the untreated control sites. The MCAF combined with EMD without GIC filling could not provide statistically significant decrease in DH. The GIC placed subgingivally may result in increase of PPD and BOP that indicate gingival inflammation.

Key words: non-carious cervical lesions (NCCL), gingival recession, dentin hypersensitivity, modified coronally advanced flap (MCAF), subepithelial connective tissue graft (SCTG), enamel matrix derivative (EMD), resin-modified glass ionomer cement, root coverage

\section{Pályázat Körmöczi-pályadíjra}

Felhívjuk a Fogorvosi Szemlében publikáló, minden rendezett MFE tagsággal rendelkező, 35 évnél fiatalabb, első szerzős cikk szerzőjét, hogy pályázzanak a 2017-es Körmöczi-pályadíjra.

Pályázni csak az 2017-ben a Fogorvosi Szemlében megjelent közleményekkel lehet. Kérjük, a közlemény pdf változatát mellékelje a pályázathoz.

\section{A pályázat beadási határideje: 2018. február 6.}

A pályázatokat, kérem, emailen juttassák el címemre.

\section{Dr. Fejérdy Pál \\ az MFE főtitkára}

fejerdy.pal@dent.semmelweis-univ.hu 